\section{JURNAL EKONOMI EFEKTIF}

ISSN : $2622-8882$, E-ISSN : 2622-9935 Jurnal Ekonomi Efektif, Vol. 4, No. 2, Januari 2022 @Prodi Manajemen Fakultas Ekonomi Universitas Pamulang

\title{
PENGARUH RASIO LIQUIDITAS TERHADAP RASIO PROFITABILITAS PADA PT SURYO TOTO INDONESIA, TBK PERIODE 2010-2020
}

\author{
Alifya Haniffah Suryaman ${ }^{1}$, Sugiyanto ${ }^{2 *}$ \\ Universitas Pamulang, Tangerang Selatan, Banten, Indonesia \\ alifyahaniffahs@gmail.com ${ }^{1}, \underline{\text { dosen00495@unpam.ac.id }{ }^{2 *}}$
}

Manuskrip: Oktober -2021; Ditinjau: November: -2021; Diterima: November-2021; Online: Januari -2022; Diterbitkan: Januari-2022

\begin{abstract}
ABSTRAK
Penelitian ini bertujuan untuk mengetahui pengaruh rasio liquiditas terhadap rasio profitabilitas pada PT. Suryo Toto Indonesia, Tbk. Metode yang digunakan adalah explanatory research. Teknik analisis menggunakan analisis statistik dengan pengujian regresi, korelasi, determinasi dan uji hipotesis. Hasil penelitian ini variabel Current Ratio diperoleh nilai ratarata sebesar 3,06\%. Variabel Return On Asset diperoleh nilai rata-rata 0,60\%. Current Ratio berpengaruh positif dan signifikan terhadap Return On Asset dengan nilai persamaan regresi $\mathrm{Y}=-0,068+0,220 \mathrm{X}$, dan nilai koefisien korelasi 0,646 atau memiliki tingkat hubungan yang kuat dengan nilai determinasi 41,7\%. Uji hipotesis diperoleh signifikansi $0,032<0,05$.
\end{abstract}

\section{Kata Kunci: Current Ratio, Return On Asset}

\begin{abstract}
This study aims to determine the effect of the liquidity ratio on the profitability ratio at PT. Suryo Toto Indonesia, Tbk. The method used is explanatory research. The analysis technique uses statistical analysis with regression, correlation, determination and hypothesis testing. The results of this research variable Current Ratio obtained an average value of $3.06 \%$. The Return On Assets variable obtained an average value of $0.60 \%$. Current Ratio has a positive and significant effect on Return On Assets with a regression equation value of $Y=-$ $0.068+0.220 X$, and a correlation coefficient value of 0.646 or has a strong relationship with a determination value of $41.7 \%$. Hypothesis testing obtained a significance of $0.032<0.05$.
\end{abstract}

Keywords: Current Ratio, Return On Asset 


\section{PENDAHULUAN}

\section{A. Latar Belakang Penelitian}

Suatu perusahaan memiliki tujuan ingin mendpaatkan tingkat keuntungan yang semaksimal mungkin. Diantara upaya yang dapat dilakukan seperti dengan memperbesar jumlah produksi yang dapat dijual. Salah satu faktor produksi terpenting ialah modal kerja yang digunakan perusahaan untuk membiayai operasi perusahaan demi menjamin kelangsungan hidup perusahaan. Maka dari itu, manajer keuangan harus mampu merencanakan dengan baik besarnya jumlah modal kerja yang efektif dan efisien di masa mendatang. Dalam memaksimumkan keuntungan selalu ada pertukaran dengan risiko. Semakin besar risiko yang dihadapi akan semakin besar pula keuntungan yang diharapkan. Seumpama kita diminta memilih antara dua proyek yang mempunyai risiko yang sama, kita akan memilih proyek yang akan memberikan imbalan atau perolehan yang lebih besar. Namun situasi yang sering dihadapi adalah apakah perolehan yang akan diterima cukup memadai untuk menutup risiko yang dihadapi. Pola yang dikembangkan untuk mengatasi masalah keuntungan dan risiko adalah memaksimumkan laba (maximize profit) disamping meminimumkan risiko (minimizing risk) (Budi Raharjo, 2007).

Profitabilitas menggambarkan kemampuan perusahaan untuk mendapatkan laba melalui semua kemampuan dan sumber yang ada seperti kegiatan penjualan, kas, modal, jumlah karyawan, jumlah cabang dan sebagainya. Rasio profitabilitas mengukur efektivitas manajemen secara keseluruhan yang ditunjukkan dengan besar kecilnya tingkat keuntungan yang diperoleh dalam hubungannya dengan penjualan maupun investasi (Sofyan Syafri Harahap, 2002).

Likuiditas merupakan suatu kondisi dari suatu perusahaan yang menunjukan kemampuan perusahaan untuk memenuhi kewajiban dalam jangka pendek dan dalam waktu yang tidak terlalu lama atau selalu siap jika suatu saat ditagih. Apabila perusahaan memiliki aktiva lancar lebih besar dari pada hutang lancar maka seharusnya perusahaan harus dapat memenuhi kewajiban keuangan tepat pada waktunya. Dengan kata lain, likuiditasnya bagus, namun sebaliknya jika perusahaan tidak mampu melaksanakan kewajiban pada saat ditagih, berarti hutang lancarnya lebih besar dari pada aktiva lancarnya, berarti dapat pula ditafsirkan dalam kondisi likuid (Abdulah Amrin, 2009). Mengacu pada kemampuan perusahaan untuk membayar untuk membayar beban-beban lancar dari operasinya (biasanya satu tahun atau kurang) dan hutang yang jatuh tempo. Enam ukuran likuiditas yang penting adalah perputaran piutang usaha, perputaran persediaan, rasio lancar, rasio cepat, dan rasio arus kas. Semakin tinggi rasio ini, semakin baik dan tinggi evaluasi terhadap profitabilitas perusahaan (Edward, Kung $\mathrm{H}$ Chen, Gery dan Thomas,2007).

Likuiditas mengukur kemampuan perusahaan untuk melunasi kewajiban utang jangka pendek tepat pada waktunya, termasuk melunasi bagian hutang jangka panjang yang jatuh tempo pada tahun bersangkutan. Likuiditas yang tinggi merupakan indikator bahwa risiko perusahaan rendah. Artinya perusahaan aman dari kemungkinan kegagalan membayar berbagai kewajiban lancar (Handono Mardiyanto, 2009).

Perusahaan semakin tinggi rasio lancar, seharusnya semakin besar kemampuan untuk membayar tagihannya. Rasio ini harus dianggap sebagai ukuran besar karena tidak mempertimbangkan likuiditas komponen individual aktiva lancar. Perusahaan dengan aktiva lancar terdiri dari kas dan piutang tanpa jatuh tempo biasanya dianggap lebih likuid daripada perusahaan yang aktiva lancarnya terdiri dari persediaan (Van Horn, James C dan John M Wachowiez, 2000). 
Perkembangan tingkat liquiditas maupun profitabilitas PT. Suryo Toto Indonesia, Tbk tahun 2010-2020 mengalami perkembangan yang fluktuasi dengan capaian current ratio rata-rata per tahun sebesar 3,33\% dan capaian return on asset rata-rata per tahun sebesar $0,63 \%$. Dengan capai tersebut Likuiditas yang tinggi merupakan indikator bahwa resiko perusahaan rendah. Artinya, perusahaan aman dari kemungkinan kegagalan membayar berbagai kewajiban lancar. Namun hal itu harus merelakan rendahnya tingkat profitabilitas, yang akan berdampak terhadap rendahnya pertumbuhan perusahaan. Sebaliknya, jika perusahaan menginginkan profitabilitas yang tinggi, perusahaan harus bersedia menghadapi rendahnya likuiditas atau risiko yang kian meningkat atas kegagalan membayar atas kegagalan membayar kewajiban jangka pendek (yang bisa menyebabkan kebangkrutan usaha). Ketika profitabilitas perusahaan turun menandakan bahwa kinerja yang kurang baik dalam pencapaian laba perusahaan. Tetapi perusahaan masih dapat meningkatkan profitabilitas dengan cara memaksimal penggunaan hutang dalam menunjang yang terlihat dari solvabilitas sehingga dimana profitabilitas perusahaan akan meningkat seiring dengan peningkatan solvabilitas sebagaimana yang dinyatakan oleh I Made Sudana (2011:158) yang mengungkapkan bahwa Pengaruh hutang dalam pembelanjaan investasi perusahaan dapat mempengaruhi kemampuan perusahaan untuk menghasilkan laba atas modal yang digunakan (ROA).

Berdasarkan gambaran tersebut peneliti tertarik untuk meneliti mengenai "Pengaruh Rasio Liquiditas Terhadap Rasio Profitabilitas Pada PT. Suryo Toto Indonesia Tbk Periode Tahun 2010-2020”.

\section{B. Rumusan Masalah}

1. Bagaimana Current Ratio pada pada PT. Suryo Toto Indonesia, Tbk?.

2. Bagaimana Return On Asset pada PT. Suryo Toto Indonesia, Tbk ?.

3. Adakah pengaruh antara Current Ratio terhadap Return On Asset pada PT. Suryo Toto Indonesia, Tbk?.

\section{Tujuan Penelitian}

1. Untuk mengetahui kondisi Current Ratio pada PT. Suryo Toto Indonesia, Tbk.

2. Untuk mengetahui kondisi Return On Asset pada PT. Suryo Toto Indonesia, Tbk.

3. Untuk mengetahui pengaruh antara Current Ratio terhadap Return On Asset pada PT. Suryo Toto Indonesia, Tbk.

\section{METODE PENELITIAN}

\section{Populasi}

Populasi dalam penelitian ini laporan keuangan PT. Suryo Toto Indonesia, Tbk selama 10 tahun

\section{Sampel}

Teknik pengambilan sampling dalam penelitian ini adalah samplel jenuh, dimana semua anggota populasi dijadikan sebagai sampel. Dengan demikian sampel dalam penelitian ini laporan keuangan PT. Suryo Toto Indonesia, Tbk selama 10 tahun.

\section{Jenis Penelitian}

Jenis penelitian yang dipakai adalah asosiatif, dimana tujuannya adalah untuk mengetahui mencari keterhubungan antara variabel independen terhadap variabel dependennya

\section{Metode Analisis Data}

Dalam menganalisis data digunakan uji validitas, uji reliabilitas, analisis regresi linier sederhana, koefisien korelasi, koefisien determinasi dan uji hipotesis. 


\section{HASIL PENELITIAN}

\section{Analisis Deskriptif}

Pada pengujian ini digunakan untuk mengetahui skor minimum dan maksimum skor tertinggi, ratting score dan standar deviasi dari masing-masing variabel. Adapun hasilnya sebagai berikut:

Tabel 1. Hasil Analisis Descriptive Statistics

Descriptive Statistics

\begin{tabular}{lr|r|r|r|r} 
& $\mathrm{N}$ & \multicolumn{1}{c}{ Minimum } & Maximum & \multicolumn{1}{c}{ Mean } & \multicolumn{1}{c}{ Std. Deviation } \\
\hline Current Ratio (X) & 11 & 1.52 & 3.68 & 3.0609 & .63508 \\
\hline Return On Asset (Y) & 11 & .24 & .89 & .6055 & .21644 \\
\hline Valid N (listwise) & 11 & & & & \\
\hline
\end{tabular}

Current Ratio diperoleh nilai minimum sebesar 1,53\% dan nilai maximum 3,68\% dengan rata-rata sebesar 3,06\% dengan standar deviasi 0,635\%. Return On Asset diperoleh nilai minimum sebesar $0,24 \%$ dan nilai maximum $0,89 \%$ dengan rata-rata sebesar $0,60 \%$ dengan standar deviasi $0,21 \%$.

\section{Analisis Verifikatif}

Pada analisis ini dimaksudkan untuk mengetahui pengaruh variabel independen terhadap variabel dependen. Adapun hasil pengujian sebagai berikut:

\section{a. Analisis Regresi Linier Sederhana}

Uji regresi ini dimaksudkan untuk mengetahui perubahan variabel dependen jika variabel independen mengalami perubahan. Adapun hasil pengujiannya sebagai berikut:

Tabel 2. Hasil Pengujian Regresi Linier Sederhana

\begin{tabular}{|c|c|c|c|c|c|c|}
\hline \multicolumn{7}{|c|}{ Coefficients ${ }^{\mathrm{a}}$} \\
\hline & & \multicolumn{2}{|c|}{$\begin{array}{l}\text { Unstandardized } \\
\text { Coefficients }\end{array}$} & \multirow{2}{*}{$\begin{array}{c}\text { Standardized } \\
\text { Coefficients } \\
\text { Beta }\end{array}$} & \multirow[b]{2}{*}{$\mathrm{t}$} & \multirow[b]{2}{*}{ Sig. } \\
\hline & & $\mathrm{B}$ & Std. Error & & & \\
\hline \multirow[t]{2}{*}{1} & (Constant) & -.068 & .271 & & -.253 & .806 \\
\hline & Current Ratio & .220 & .087 & .646 & 2.539 & .032 \\
\hline
\end{tabular}

a. Dependent Variable: Return on Asset

Berdasarkan hasil pengujian pada tabel di atas, diperoleh persamaan regresi $\mathrm{Y}$ $=-0,068+0,220 X$. Dari persamaan tersebut dijelaskan sebagai berikut:

1) Konstanta sebesar -0,068 diartikan jika Current Ratio tidak ada, maka telah terdapat nilai Return On Asset sebesar -0,068 point.

2) Koefisien regresi Current Ratio sebesar 0,220, angka ini positif artinya setiap ada peningkatan Current Ratio sebesar 0,220 point maka Return On Asset juga akan mengalami peningkatan sebesar 0,220 point.

\section{b. Analisis Koefisien Korelasi}

Analisis koefisien korelasi dimaksudkan untuk mengetahui tingkt kekuatan hubungan dari variabel independen terhadap variabel dependen baik secara parsial maupun simultan. Adapun hasil pengujian sebagai berikut:

Tabel 3. Hasil Pengujian Koefisien Korelasi Current Ratio Terhadap Return On

Asset.

Correlations $^{\mathrm{b}}$

\begin{tabular}{llr|r} 
& & Current Ratio & \multicolumn{1}{c}{ Return on Asset } \\
\hline Current Ratio & Pearson Correlation & 1 & $.646^{*}$ \\
\cline { 2 - 4 } & Sig. (2-tailed) & & .032 \\
\hline Return on Asset & Pearson Correlation & $.646^{*}$ & 1 \\
\cline { 2 - 4 } & Sig. (2-tailed) & .032 & \\
\hline
\end{tabular}


*. Correlation is significant at the 0.05 level (2-tailed).

b. Listwise $\mathrm{N}=11$

Berdasarkan hasil pengujian diperoleh nilai korelasi sebesar 0,646 artinya Current Ratio memiliki hubungan yang kuat terhadap Return On Asset.

\section{c. Analisis Koefisien Determinasi}

Analisis koefisien determinasi dimaksudkan untuk mengetahui besarnya persentase pengaruh dari variabel independen terhadap variabel dependen. Adapun hasil pengujian sebagai berikut:

Tabel 4. Hasil Pengujian Koefisien Determinasi Current Ratio Terhadap Return On Asset.

Model Summary

\begin{tabular}{l|l|c|c|c} 
& & & \multicolumn{2}{c}{ Model Summary } \\
Model & R & \multicolumn{2}{c}{$\begin{array}{c}\text { Adjusted R } \\
\text { R Square }\end{array}$} & \multicolumn{2}{c}{$\begin{array}{c}\text { Std. Error of the } \\
\text { Estimate }\end{array}$} \\
\hline 1 & & .417 & .353 & .17415 \\
\hline
\end{tabular}

a. Predictors: (Constant), Current Ratio

Berdasarkan hasil pengujian diperoleh nilai determinasi sebesar 0,417 artinya Current Ratio memiliki kontribusi pengaruh sebesar $41,7 \%$ terhadap Return On Asset.

\section{d. Uji Hipotesis}

Pengujian hipotesis dengan uji t digunakan untuk mengetahui hipotesis mana yang diterima. Rumusan hipotesis: Terdapat pengaruh yang signifikan antara Current Ratio terhadap Return On Asset.

Tabel 5. Hasil Uji Hipotesis Current Ratio Terhadap Return On Asset.

\section{Coefficients $^{\mathrm{a}}$}

Unstandardized

Coefficients

Standardized

Coefficients

\begin{tabular}{|c|c|c|c|c|c|}
\hline Model & $\mathrm{B}$ & Std. Error & Beta & $\mathrm{t}$ & Sig. \\
\hline (Constant) & -.068 & .271 & & -.253 & .806 \\
\hline Current Ratio & .220 & .087 & .646 & 2.539 & .032 \\
\hline
\end{tabular}

a. Dependent Variable: Return on Asset

Berdasarkan hasil pengujian pada tabel di atas, diperoleh nilai t hitung $>\mathrm{t}$ tabel atau $(2,539>2,305)$, dengan demikian hipotesis yang diajukan bahwa terdapat pengaruh yang signifikan atara Current Ratio terhadap Return On Asset diterima.

\section{Pembahasan Hasil Penelitian}

\section{Kondisi Jawaban Responden Variabel Current Ratio}

Berdasarkan data empiris dan analisis data, variabel Current Ratio diperoleh nilai rata-rata per tahun sebesar $3,06 \%$.

\section{Kondisi Jawaban Responden Variabel Return On Asset}

Berdasarkan data empiris dan analisis data, variabel Return On Asset diperoleh nilai rata-rata per tahun sebesar $0,60 \%$.

\section{Pengaruh Current Ratio Terhadap Return On Asset}

Current Ratio berpengaruh signifikan terhadap Return On Asset dengan persamaan regresi $\mathrm{Y}=-0,068+0,220 \mathrm{X}$, nilai korelasi sebesar 0,646 atau memiliki hubungan yang kuat dengan kontribusi pengaruh sebesar $41,7 \%$. Pengujian hipotesis diperoleh nilai $\mathrm{t}$ hitung $>\mathrm{t}$ tabel atau $(2,539>2,305)$. Dengan demikian hipotesis yang 
diajukan bahwa terdapat berpengaruh signifikan antara Current Ratio terhadap Return

On Asset diterima.

\section{KESIMPULAN DAN SARAN}

\section{Kesimpulan}

a. Kondisi variabel Current Ratio berdasar pada periode laporan keuangan 10 tahun diperoleh Current Ratio rata-rata sebesar 3,06\%.

b. Kondisi variabel Return On Asset berdasar pada periode laporan keuangan 10 tahun diperoleh Current Ratio rata-rata sebesar $0,60 \%$.

c. Current Ratio berpengaruh signifikan terhadap Return On Asset dengan persamaan regresi $\mathrm{Y}=-0,068+0,220 \mathrm{X}$, nilai korelasi sebesar 0,646 atau kuat dan kontribusi pengaruh sebesar $41,7 \%$ sedangkan sisanya sebesar $57,9 \%$ dipengaruhi faktor lain. Uji hipotesis diperoleh nilai t hitung $>\mathrm{t}$ tabel atau $(2,539>2,305)$.

\section{Saran}

a. Perusahaan harus memperhatikan tingkat likuiditasnya, dimana kemampuan perusahaan dalam memenuhi kewajiban-kewajiban masih belum optimal karena tingkat kemampuan perusahaan dibeberapa tahun penelitian banyak mengalami penurunan. Walaupun dalam membayarkan hutang perusahaan tetap dapat terkendali.

b. Perusahaan harus memperhatikan tingkat profitabilitas, Hal ini masih dapat diperbaiki dengan mengupayakan keuntungan yang maksimal diantaranya mengupayakan tagihan atau piutang yang bermasalah atau semaksimalkan pengembalian secara tepat waktu yang selanjutnya akan menambah jumlah keuntungan.

\section{DAFTAR PUSTAKA}

Agus Harjito \& Martono, (2010) "Manajemen Keuangan" Yogyakarta: Penerbit Ekonisia. Agus Sartono. (2010). "Manajemen Keuangan Toeri dan Aplikasi", Edisi keempat, Yogyakarta: Penerbit BPFE.

Algifari. (2015). “Analisis Regresi untuk Bisnis dan Ekonomi”. Yogyakarta: BPFE.

Arikunto, Suharsimi (2014). "Prosedur Penelitian Suatu Pendekatan Praktek". Jakarta: Rineka Cipta.

Bambang Riyanto, (2011). "Dasar-dasar Pembelanjaan Perusahaan". Edisi ke empat, BPFE Yogyakarta.

Brigham, F. Eugene dan Joel, F. Houston. "Dasar-dasar Manajemen Keuangan".Edisi Kesepuluh, JilidI. Salemba Empat. Jakarta : 2008

Fahmi, Irham (2012), "Pengantar Manajemen Keuangan" Cetakan pertama. Bandung: Penerbit Alfabeta.

Harahap, Sofyan Safri. “Analisis Kritis Atas Laporan Keuangan”. Raja Grafindo Persada. Jakarta : 2002

Hasibuan, Malayu S.P “Pengantar Manajemen”. CV. Alfabeta. Bandung : 2012

Hushan, Suad dan Enny Pudjiastuti. "Dasar-dasar Manajemen Keuangan".Edisi Keenam. UPP STIM YKPN. Jogyakarta:2012

Imam Ghozali (2017). "Aplikasi Analisis Multivariate Dengan Program SPSS". Edisi Kelima. Semarang: Badan Penerbit Undip.

Istijanto (2014) "Riset Sumber Daya Manusia". Jakarta: PT. Gramedia Pustaka

Jasmani, J. (2018). Pengaruh Kinerja Keuangan Terhadap Harga Saham (Analisis Pada Perusahaan Property dan Real Estate Yang Go Public di Bursa Efek Indonesia. Jurnal 
Akuntansi Indonesia, 12(2).

Jasmani, J. (2019). The Effect of Liquidity and Working Capital Turnover on Profitability at PT. Sumber Cipta Multiniaga, South Jakarta. PINISI Discretion Review, 3(1), 2938.

Kasmir (2010), “Analisis Laporan keuangan”, penerbit raja grafindo persada, Jakarta

Kasmir, (2010). “Pengantar Manajemen Keuangan”, Edisi Pertama, Cetakan kedua, Jakarta: Penerbit Prenada Media.

Kasmir. (2012) "Pengantar Manajemen Keuangan", Edisi Pertama, Cetakan kedua, Jakarta: Prenada Media.

Kasmir. “Analisis Laporan Keuangan”. PT. Rajawali Persada Jakarta : 2014

Kasmir. “Analisis Laporan Keuangan”. Raja Grafindo Persada Jakarta : 2012

Kharis, Ismu Fadli (2011). "Studi Mengenai Impulse Buying dalam Penjualan Online". Semarang : Skripsi Universitas Diponegoro

Martono dan Agus Harjito, (2011). "Manajemen Keuangan”, Jakarta: Penerbit Ekonisia..

Martono dan Agus Harjito. “Manajemen Keuangan”. Ekonosia.Yogyakarta : 2010

Munawir (2010), “Analisis Laporan Keuangan”, Edisi Ke Empat, Penerbit Liberty, Yogyakarta.

Rodoni, A, Ali, H. “Manajemen Keuangan”. Mitra Wacana Media. Jakarta : 2010

S.Munawir.”Analisa Laporan Keuangan". Liberty. Jogyakarta:2013 (Edisi Keempat)

Santoso, Singgih (2015). "Menguasai Statistik Multivariat". Jakarta: PT Elex Media Komputindo.

Sartono, "Manajemen Keuangan Aplikasi Dan Teori”, Edisi Keempat, BPFE, Yogyakarta, 2008.

Sawir, (2003). "Analisis Kinerja Keuangan dan Perencanaan Keuangan Perusahaan”, Cetakan ketiga, Jakarta: Penerbit PT. Gramedia Pustaka Utama.

Siswanto, H, B. “Pengantar Manajemen”. BumiAksara. Jakarta : 2011.

Sugiyarso, G. dan F. Winarni, "Manajemen Keuangan (Pemahaman Laporan Keuangan, Pengelolaan Aktiva, Kewajiban dan Modal serta Pengukuran

Sugiyono (2017), "Metode Penelitian Administrasi : dilengkapi dengan Metode R \& D". Bandung: Alfabeta.

Sugiyono. "Metode Penelitian Kuantitatif, Kualitatif dan R\&D". Alfabeta.Bandung : 2009

Sutrisno. "Manajemen Keuangan Teori, Konsep, dan Aplikasi”. Ekonosia.Yogyakarta : 2005.

Wijaya, Toni. “Cepat Menguasai SPSS 20” Cahaya Atma Pustaka. Yogyakarta:2012

Wiratna Sujarweni, V. “Metodologi Penelitian”.Pustaka Baru Press.Yogyakarta : 2014. 